Article

\title{
Dietary Deoxynivalenol (DON) May Impair the Epithelial Barrier and Modulate the Cytokine Signaling in the Intestine of Atlantic Salmon (Salmo salar)
}

\author{
Torfinn Moldal ${ }^{1}{ }^{1}$, Aksel Bernhoft ${ }^{1}$, Grethe Rosenlund ${ }^{2}$, Magne Kaldhusdal ${ }^{1}$ \\ and Erling Olaf Koppang ${ }^{3, *}$ \\ 1 Norwegian Veterinary Institute, Post box 750 Sentrum, 0106 Oslo, Norway; torfinn.moldal@vetinst.no (T.M.); \\ aksel.bernhoft@vetinst.no (A.B.); magne.kaldhusdal@vetinst.no (M.K.) \\ 2 Skretting ARC, Post box 48, 4001 Stavanger, Norway; grethe.rosenlund@skretting.com \\ 3 Department of Basic Sciences and Aquatic Medicine, Norwegian University of Life Sciences, \\ Post box 369 Sentrum, 0102 Oslo, Norway \\ * Correspondence: erling.o.koppang@nmbu.no
}

Received: 4 August 2018; Accepted: 12 September 2018; Published: 14 September 2018

\begin{abstract}
Impaired growth, immunity, and intestinal barrier in mammals, poultry, and carp have been attributed to the mycotoxin deoxynivalenol (DON). The increased use of plant ingredients in aquaculture feed implies a risk for contamination with mycotoxins. The effects of dietary DON were explored in 12-month-old Atlantic salmon (Salmo salar) (start weight of $58 \mathrm{~g}$ ) that were offered a standard feed with non-detectable levels of mycotoxins (control group) or $5.5 \mathrm{mg}$ DON $/ \mathrm{kg}$ feed (DON group). Each group comprised two tanks with 25 fish per tank. Five fish from each tank were sampled eight weeks after the start of the feeding trial, when mean weights for the control and DON groups were $123.2 \mathrm{~g}$ and $80.2 \mathrm{~g}$, respectively. The relative expression of markers for three tight junction proteins (claudin 25b, occludin, and tricellulin) were lower, whereas the relative expression of a marker for proliferating cell nuclear antigen was higher in both the mid-intestine and the distal intestine in fish fed DON compared with fish from the control group. The relative expression of markers for two suppressors of cytokine signaling (SOCS1 and SOCS2) were higher in the distal intestine in fish fed DON. There was no indication of inflammation attributed to the feed in any intestinal segments. Our findings suggest that dietary DON impaired the intestinal integrity, while an inflammatory response appeared to be mitigated by suppressors of cytokine signaling. A dysfunctional intestinal barrier may have contributed to the impaired production performance observed in the DON group.
\end{abstract}

Keywords: atlantic salmon; deoxynivalenol; feed; intestine; PCR; proliferating cell nuclear antigen; suppressor of cytokine signaling; tight junctions

Key Contribution: Dietary DON at a level of $5.5 \mathrm{mg} / \mathrm{kg}$ feed revealed lower expression of markers for tight junction proteins and higher expression of a marker for proliferating cell nuclear antigen in the intestine of Atlantic salmon. A dysfunctional intestinal barrier may have contributed to impaired production performance.

\section{Introduction}

Atlantic salmon (Salmo salar) is one of the most important species in aquaculture worldwide. Salmonids are carnivores by nature, but raw materials of vegetable origin are increasingly used in 
feed for farmed salmonids due to a limited supply of fish meal and fish oil [1-3]. The use of cereals in feeds for farmed fish implies a risk for contamination with mycotoxins that are metabolites of mold capable of having acute toxic, carcinogenic, mutagenic, teratogenic, immunotoxic, or hormonal effects in mammals [4]. Deoxynivalenol (DON) is one of the major mycotoxins produced by Fusarium spp. [5]. The current European Union (EU) legislation establishes $8000 \mu \mathrm{g} / \mathrm{kg}$ as a maximum guidance value for DON in cereals and cereal products (with an exception for maize by-products) intended for animal feed and $5000 \mu \mathrm{g} / \mathrm{mg}$ as a maximum guidance value for complementary and complete feeding stuffs [6,7]. The surveillance of feeds for salmonids in Norwegian aquaculture shows levels of mycotoxins far below the current guidance levels [8], but accidental intermixture may occur.

Mycotoxins do not appear to pose a hazard to the consumer, because carry-over is considered negligible in fillets from gilthead seabream (Sparus aurata) and Atlantic salmon experimentally exposed to dietary DON at levels up to $5.5 \mathrm{mg} / \mathrm{kg}$ feed $[9,10]$. However, adverse effects in fish ingesting feed contaminated by mycotoxins have been observed. In Atlantic salmon and rainbow trout (Oncorhynchus mykiss), there appears to be a linearity between increasing dietary levels of DON up to $5.5 \mathrm{mg} / \mathrm{kg}$ feed and $2.6 \mathrm{mg} / \mathrm{kg}$ feed, respectively, and decreasing weight gain and growth rate [11,12]. Furthermore, dose-related alterations in some blood parameters were shown in Atlantic salmon and rainbow trout [11,13], and pathological changes in the liver characterized by subcapsular hemorrhage and edema were observed in a number of DON-exposed rainbow trout [12]. In carp (Cyprinus carpio), the relative expression of markers for both pro- and anti-inflammatory cytokines as well as enzymes in different organs including the intestine were activated by feed-borne DON at a concentration of $953 \mu \mathrm{g} / \mathrm{kg}$ feed with an adaption over time [14].

The intestine is an important barrier for protection against pathogens in addition to its main task in digestion. Exposure of the intestine to mycotoxins, either via feed or gavage, may impair the intestinal integrity and consequently alter the absorption of nutrients as well as facilitate the invasion of microbes. In pigs exposed to dietary DON at levels from 0.9 to $3.5 \mathrm{mg} / \mathrm{kg}$ feed, the relative expression of markers for several tight junction proteins (TJs) and inflammatory markers in intestines were affected [15-17]. The relative expression of markers for certain cytokines was down-regulated in the intestines of broiler chickens on a diet contaminated with $10 \mathrm{mg}$ DON/kg feed [18]. Furthermore, DON predisposes to the development of necrotic enteritis in broiler chickens at a contamination level of 3 to $4 \mathrm{mg} / \mathrm{kg}$ feed [19].

Dose-dependent up-regulation of pro-inflammatory cytokines, followed by up-regulation of suppressors of cytokine signaling and subsequent basal expression of the cytokines, has been demonstrated in several organs in mice orally exposed to DON over a dose range of $0.1-12.5 \mathrm{mg} / \mathrm{kg}$ body weight in short-time experiments [20]. Altered transcript levels as well as protein expression for TJs, decreased transepithelial electrical resistance, and increased permeability as a result of exposure to DON have been observed in several in vitro and in vivo models indicating functional effects [21].

So far, little is known about the impact of dietary mycotoxins on intestinal health of fish in general and of Atlantic salmon in particular. The aim of this study was to investigate in Atlantic salmon the long-term impact of dietary DON at a level of $5.5 \mathrm{mg} / \mathrm{kg}$ feed on parameters related to the epithelial barrier of the intestine (relative expression of markers for tight junction proteins and proliferating cell nuclear antigen as well as goblet cell density), cytokine-mediated inflammation (relative expression of a marker for interleukin $1 \beta$ ), and suppression of cytokine signaling (relative expression of markers for SOCS1 and SOCS2), as well as morphologic responses to intestinal insults. The chosen DON level was slightly higher than the maximum recommended level ( $5 \mathrm{mg}$ DON $/ \mathrm{kg}$ feed) established in the European Union's current legislation on animal feed. 


\section{Results}

\subsection{Gene Expression Analysis by Real-Time PCR}

The relative expression of markers for the tight junction proteins claudin 25b, occludin, and tricellulin was significantly lower in both the mid-intestine and the distal intestine from fish fed DON compared with fish from the control group (see Table 1 and Figure 1). The relative expression of the marker for occludin was also lower in the pyloric ceca from fish fed DON compared with the controls.
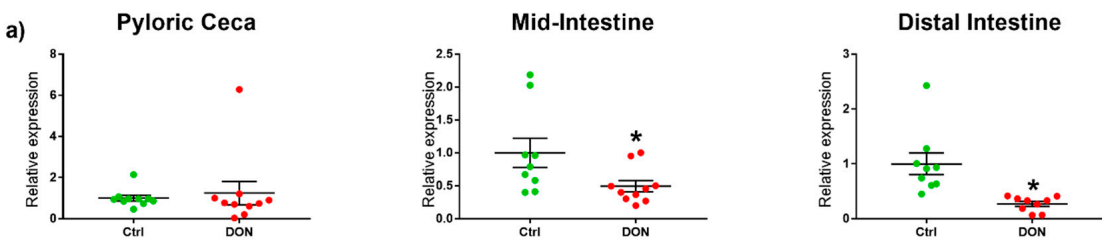

b)
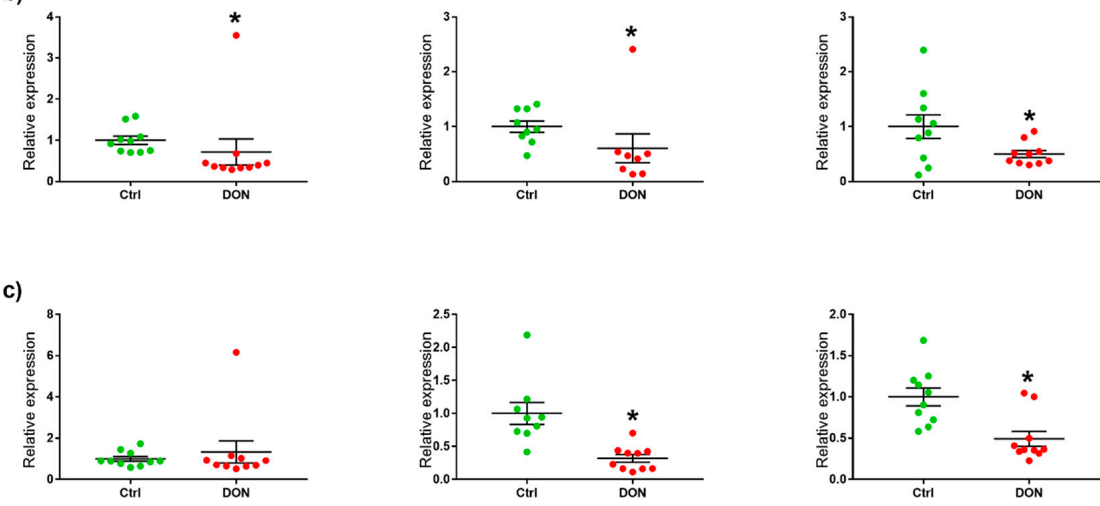

Figure 1. Relative expression of markers for tight junction proteins in the intestine of salmon fed deoxynivalenol (DON) $(5.5 \mathrm{mg} / \mathrm{kg}$ feed) or no DON (controls) for eight weeks. * Significant differences (unpaired $t$-test or Mann-Whitney $\mathrm{U}$ test, $p<0.05$ ) between the experimental groups in the same intestinal segment. The relative expression of markers for the tight junction proteins (a) claudin $25 \mathrm{~b}$, (b) occludin, and (c) tricellulin were significantly lower in both the mid-intestine and the distal intestine from fish fed DON compared with the controls. The relative expression of the marker for occludin was also significantly lower in the pyloric ceca from fish fed DON compared with the controls.

On the other hand, the relative expression of a marker for proliferating cell nuclear antigen (PCNA) was significantly higher in all intestinal segments in fish fed DON compared with the controls (see Table 1 and Figure 2).
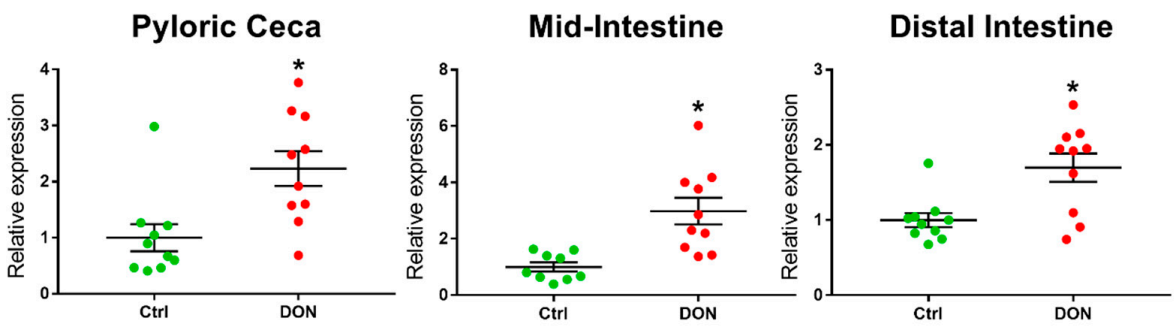

Figure 2. Relative expression of a marker for proliferating cell nuclear antigen (PCNA) in the intestine of salmon fed DON (5.5 mg/kg feed) or no DON (controls) for eight weeks. * Significant differences (unpaired $t$-test or Mann-Whitney $\mathrm{U}$ test, $p<0.05$ ) between the experimental groups in the same intestinal segment. The relative expression of a marker for PCNA was significantly higher in all intestinal segments from fish fed DON compared with the controls. 
The relative expression of markers for the suppressors of cytokine 1 and 2 (SOCS1 and SOCS2) was significantly higher in the distal intestine in fish fed DON compared with the controls. Further, the relative expression of the marker for SOCS1 was also significantly higher in the pyloric ceca in fish fed DON compared with the controls (see Table 1 and Figure 3).

a)

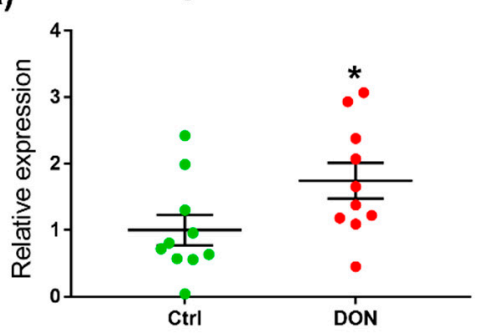

b)

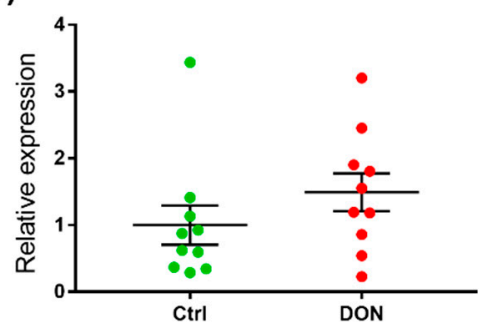

Mid-Intestine
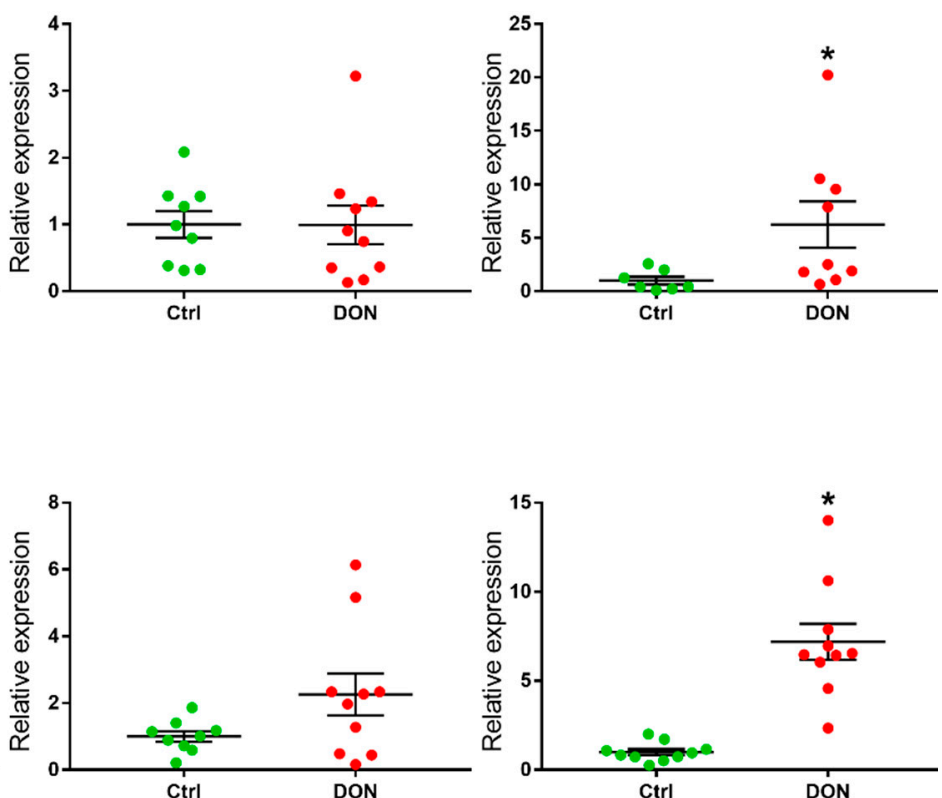

Distal Intestine

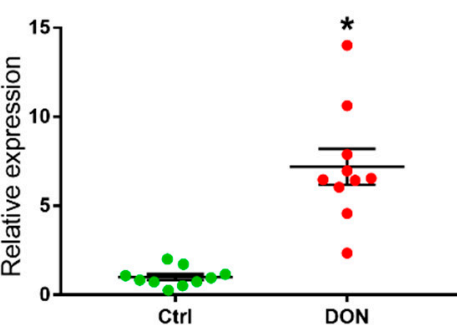

Figure 3. Relative expression of suppressors of cytokine signaling (SOCS) in the intestine of salmon fed DON (5.5 mg/kg feed) or no DON (controls) for eight weeks. * Significant differences (unpaired $t$-test or Mann-Whitney $\mathrm{U}$ test, $p<0.05$ ) between the experimental groups in the same intestinal segment. The relative expression of markers for the suppressors of cytokine signaling (a) SOCS1 and (b) SOCS2 were significantly higher in the distal intestine from fish fed DON compared with the controls. The relative expression of the marker for SOCS1 was also significantly higher in the pyloric ceca from fish fed DON compared with the controls.

There was no significant difference between the dietary groups regarding the relative expression of a marker for the cytokine interleukin $1 \beta$ in any of the intestinal segments (see Table 1).

Table 1. Relative transcription levels normalized to reference gene EF1AB in the intestine of salmon fed DON (5.5 mg/ $\mathrm{kg}$ feed) or no DON (controls) for eight weeks.

\begin{tabular}{|c|c|c|c|c|c|c|}
\hline & \multicolumn{2}{|c|}{ Pyloric Ceca } & \multicolumn{2}{|c|}{ Mid-Intestine } & \multicolumn{2}{|c|}{ Distal Intestine } \\
\hline & Control & DON & Control & DON & Control & DON \\
\hline IL-1 $\beta$ & $1 \pm 0.27^{a}$ & $0.96 \pm 0.40$ & $1 \pm 0.22^{a}$ & $0.94 \pm 0.13$ & $1 \pm 0.21^{a}$ & $1.45 \pm 0.25$ \\
\hline SOCS1 & $1 \pm 0.23$ & $1.74 \pm 0.27 *$ & $1 \pm 0.20^{a}$ & $0.99 \pm 0.29$ & $1 \pm 0.37^{c}$ & $6.24 \pm 2.17^{*, \mathrm{a}}$ \\
\hline SOCS2 & $1 \pm 0.29$ & $1.49 \pm 0.28$ & $1 \pm 0.16^{\mathrm{a}}$ & $2.26 \pm 0.63$ & $1 \pm 0.17$ & $7.19 \pm 1.01 *$ \\
\hline Claudin 25b & $1 \pm 0.14$ & $1.25 \pm 0.57$ & $1 \pm 0.22^{a}$ & $0.49 \pm 0.09 *$ & $1 \pm 0.20^{a}$ & $0.27 \pm 0.05^{*, \mathrm{a}}$ \\
\hline Occludin & $1 \pm 0.10$ & $0.72 \pm 0.32 *$ & $1 \pm 0.10^{a}$ & $0.60 \pm 0.26^{*, b}$ & $1 \pm 0.22$ & $0.50 \pm 0.07^{*}$ \\
\hline PCNA & $1 \pm 0.24$ & $2.23 \pm 0.31 *$ & $1 \pm 0.16^{a}$ & $2.98 \pm 0.47 *$ & $1 \pm 0.09$ & $1.70 \pm 0.19 *$ \\
\hline Tricellulin & $1 \pm 0.12$ & $1.34 \pm 0.54$ & $1 \pm 0.17^{a}$ & $0.32 \pm 0.06 *$ & $1 \pm 0.11$ & $0.49 \pm 0.09 *$ \\
\hline
\end{tabular}

The data for the DON group are presented as mean \pm standard error of the mean (SEM) relative to the mean \pm SEM for the control group for the same intestinal segment; * Significant differences (unpaired $t$-test or Mann-Whitney $\mathrm{U}$ test, $p<0.05$ ) between the experimental groups in the same intestinal segment. The values that differ significantly are highlighted in bold text. $n=10$ for each group/gene/intestinal segment unless otherwise stated: ${ }^{a}: n=9$, b: $n=8$, and ${ }^{c}: n=7$. 


\subsection{Histology and Immunohistochemistry}

Histological examination did not reveal pathological changes in the intestines of any fish (see Figure 4a). The polarization of the enterocytes seemed non-affected, the density of goblet cells appeared similar in both dietary groups, while proliferating cells were mainly detected at the base of the intestinal folds with an equal pattern for both groups (see Figure $4 b$ ).

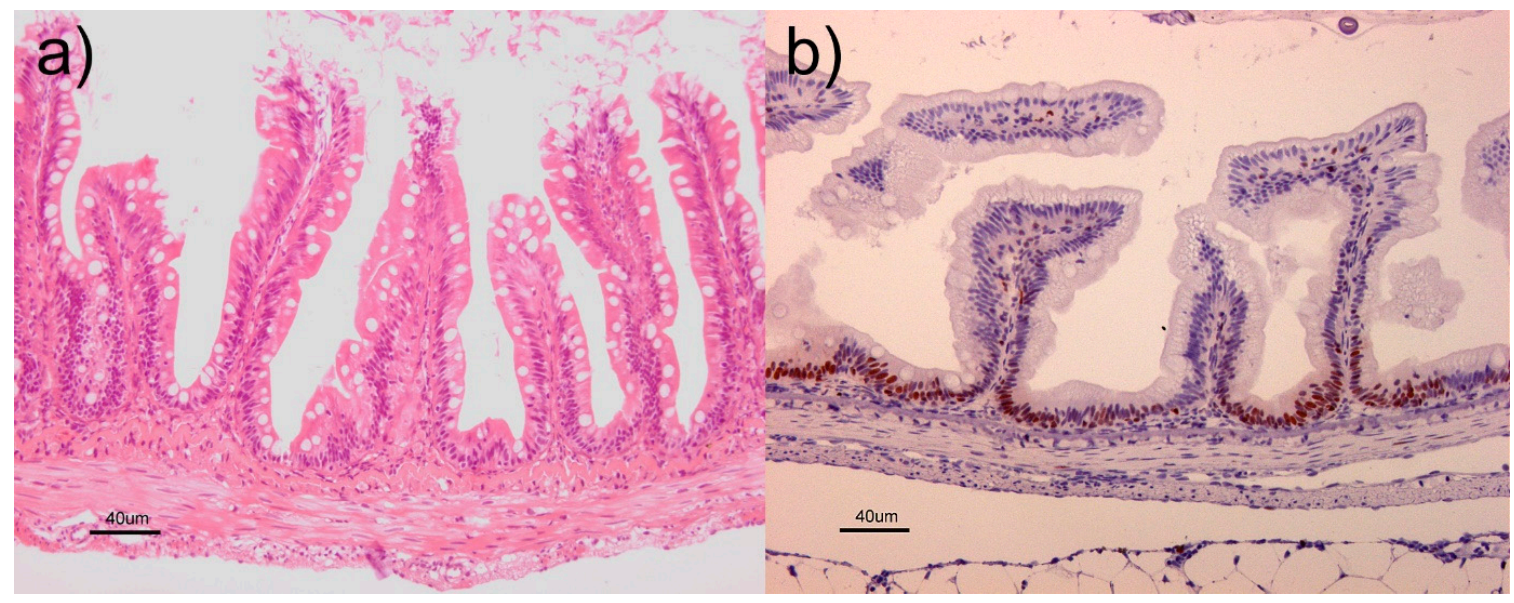

Figure 4. Micrographs of intestinal tissue. Following a histological evaluation, (a) pathological changes were not revealed in the intestines of any fish and (b) proliferating cells were detected mainly at the base of the folds with an equal pattern in the controls and the DON group.

\section{Discussion}

We found that $5.5 \mathrm{mg} \mathrm{DON} / \mathrm{kg}$ feed was associated with reduced intestinal expression of markers for three tight junction proteins (claudin 25b, occludin, and tricellulin), suggesting insufficient expression of these proteins, which could lead to an epithelial barrier impairment with sequelae affecting both structure and function of the intestine. The effect was most prominent in the distal intestine. An assumed functional impairment was confirmed by the fact that feed intake and feed efficiency were significantly reduced by DON exposure [11], and the body weight gain of the DON group was only one third of the weight gain of the fish from the control group. It was therefore surprising that we did not detect indications of intestinal inflammation (expression of a marker for IL-1 $\beta$ and histological examination) or proliferation of goblet cells (tissue sections stained with Alcian Blue (AB) and Periodic acid-Schiff (PAS) in combination) and absorptive epithelial cells (tissue sections stained with an antibody toward proliferating cell nuclear antigen (PCNA)). However, other findings suggested a subtler mechanism behind the adverse impact of DON on production performance. We detected that the relative expression of markers for two suppressors of cytokine signaling proteins (SOCS1 and SOCS2) was increased. These increased levels may have contributed to the suppression of inflammatory cytokines and morphologic inflammatory responses. We also found that the intestinal level of an mRNA marker for PCNA was increased by DON, suggesting an attempt at increased proliferation of epithelial cells. However, for some unknown reason this gene transcription did not appear to translate into the appropriate protein.

To the best of our knowledge, this is the first study addressing the possible influence of any mycotoxin on certain parameters of the intestine of Atlantic salmon (Salmo salar). The relative expression of markers for three tight junction proteins (TJs) was significantly lower in both the mid-intestine and the distal intestine in fish experimentally exposed to dietary DON for eight weeks compared with fish fed a standard diet with non-detectable levels of mycotoxins. These findings suggest that the intestinal permeability was increased leading to a leakage of fluids and a suboptimal control of paracellular influx of macromolecules as undigested food particles, pathogens, and toxins. Possible consequences include reduced growth as observed in this trial $[10,11]$ and a number of 
infections both locally and systemically. The relatively high expression of the marker for PCNA in all intestinal segments in fish exposed to DON compared with the controls may be interpreted as a local response aimed at regenerating intestinal integrity. In pigs experimentally exposed to DON in the feed, both the up- and down-regulation of markers for TJs have been reported $[15,16]$. This apparent response discrepancy might be attributed to different dosages and study periods.

In carp (Cyprinus carpio), the relative expression of markers for several cytokines was 2-3-fold higher in the intestine in fish on an experimental diet with DON at a level of $953 \mu \mathrm{g} / \mathrm{kg}$ feed compared with the controls at day 14 of the experiment, but the relative expression returned to basal levels at day 26 and day 56 [14]. In mice exposed to DON by oral gavage, both the relative expression of markers for tumor necrosis factor- $\alpha$ and interleukin 6 as well as the protein expression were rapidly induced in several organs and plasma, respectively, with a peak of $2 \mathrm{~h}$ after exposure and a subsequent decrease [20]. However, the relative expression of several suppressors of cytokine signaling (SOCS), a family of intracellular proteins that play critical roles in the regulation of innate and adaptive immune responses as well as growth and development through negative feedback on cytokine signaling, remained high for several hours with different kinetics for each SOCS and organ [22]. Functional conservation between teleosts and mammals for SOCS has been demonstrated [23], and the relatively high expression of markers for SOCS1 and SOCS2 in the distal intestine in Atlantic salmon exposed to dietary DON in our study, in combination with the absence of inflammation, suggest a successful and long-lasting response to DON in orchestrating the complex network of cytokines. Specifically, SOCS1 is central to the regulation of a number of cytokines including interferons (IFNs) and interleukins in mammals [22], and a strong and negative regulatory effect of salmon SOCS1 on type I and type II IFN-signaling has been demonstrated in cells originating from Atlantic salmon head kidney [23]. Salmon SOCS2 was only moderately affected by IFN responses in that study; however, given the analogy with SOCS2 in mammals [22], it can be assumed that in our study, SOCS2 has influenced growth hormone activity and thus contributed to the reduced growth in fish exposed to DON compared with the controls $[10,11]$. These findings underline the importance of taking into consideration the dynamics and complexity of cytokine signaling when designing studies and interpreting results.

The level of DON in the feed for the DON group was slightly higher than the maximum recommended level (5 mg DON/ $\mathrm{kg}$ feed) established in the European Union's current legislation on animal feed. The surveillance of feeds for salmonids in Norwegian aquaculture shows in general low levels of mycotoxins [8], but a negative impact on certain biochemical parameters have already been observed in Atlantic salmon at $2 \mathrm{mg}$ DON $/ \mathrm{kg}$ feed [11].

Previous studies have produced findings suggesting that the distal intestine (also designated as the second segment of the mid-intestine and posterior intestine) is more vulnerable to disease and dysfunction and particularly important for the immunological defense of Atlantic salmon [24-26]. These works showed that the uptake of gold-labelled bovine serum albumin was restricted to the distal intestine and that the transcript levels of selected immune parameters in general were higher in this intestinal segment, where an inflammation associated with soy-bean meal also occurs in this species. Our results agree with the results from these studies as DON appeared to impair the epithelial barrier and modulate the cytokine signaling in the distal intestine to a larger degree than the other intestinal segments examined.

Studies applying real-time PCR have demonstrated that markers for several tight junction proteins, among these claudin $25 \mathrm{~b}$, occludin, and tricellulin, are expressed in the intestine of Atlantic salmon $[27,28]$, and that the expression levels are elevated when juvenile Atlantic salmon are transferred to seawater, suggesting that they are involved in the reorganization of intestinal epithelium and have possibly changed the paracellular permeability. Studies on the protein expression of junctional proteins to reveal whether there is an association between gene expression and protein expression would be of great interest. Unfortunately, research in Atlantic salmon is hampered by the lack of relevant antibodies for performing immunohistochemistry or western blot. However, our findings demonstrate that DON-containing feed may influence certain parameters in the intestine 
in several ways that separately and in combination may have an adverse impact on fish growth and health. Because the increased use of raw materials of plant origin in aquaculture feed implies a risk for contamination of mycotoxins, the continued surveillance of feeds for the presence of mycotoxins as well as more research exploring the effects of mycotoxins on health and productivity are needed.

\section{Materials and Methods}

\subsection{Animal Ethics and Rearing}

The feed trial took place at the Skretting ARC Lerang Research Station that is approved by the Norwegian Animal Research Authority. The trial was approved by the responsible person for animal ethics at the facility on 12 April 2011 and carried out in accordance with the recommendations in the current animal welfare regulations in Norway (FOR-1996-01-15-23).

The trial is described in detail elsewhere [10,11]. Briefly, juvenile post-smolt Atlantic salmon (Salmo salar) (SalmoBreed, Bergen, Norway, 12 months old, both genders) with an average weight of approximately $58 \mathrm{~g}$ were randomly allocated into tanks supplied by flow-through seawater. All the fish were vaccinated intraperitonally against Aeromonas salmonicidae three weeks after the start of the experiment.

\subsection{Study Design and Sampling}

This experiment was designed with two treatment groups (see Figure 5): a control group fed a standard pelleted feed (Spirit $3 \mathrm{~mm}$, Skretting, Stavanger, Norway) with non-detectable levels of mycotoxins and a group offered the same feed coated with pure deoxynivalenol (DON) (Biopure standard DON; lot \#06221Z, degree of purity $99.4 \%$, Romer Labs, Tulln, Austria) to a level of $5.5 \mathrm{mg}$ DON $/ \mathrm{kg}$ feed. Each group comprised two tanks with 25 fish per tank. Five fish from each tank were sampled eight weeks after the start of the feeding trial, when mean weights for the control and DON fish were $123.2 \mathrm{~g}$ and $80.2 \mathrm{~g}$, respectively. Thus, the weight gain of the DON group was only one third of the weight gain in the control group. The feed efficiency was approximately 0.8 and 1.3 , respectively [11].

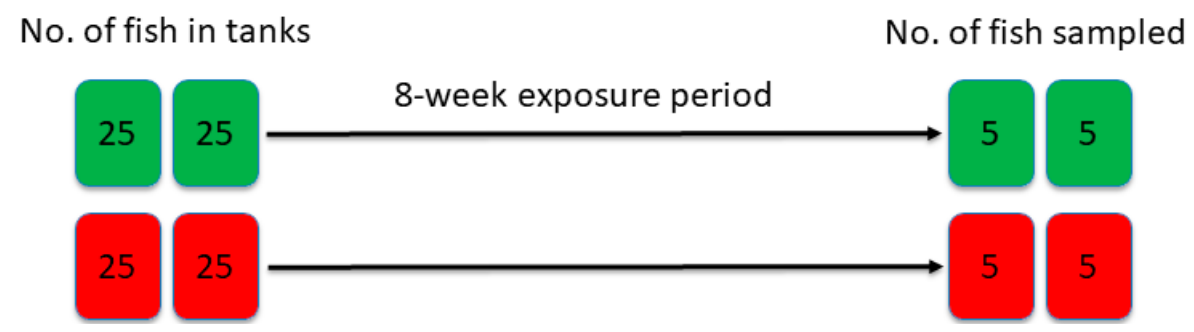

Figure 5. Design of the study on Atlantic salmon fed DON $(5.5 \mathrm{mg} / \mathrm{kg}$ diet, red color) or no DON (controls, green color) for eight weeks. Five fish from each tank were sampled eight weeks after the start of the feeding trial.

Tissues from the pyloric ceca, the mid-intestine and distal intestine were collected on RNAlater and formalin (Figure 6). Tissues on RNAlater were stored cool for $24-48 \mathrm{~h}$ and then at $-20^{\circ} \mathrm{C}$ until further processing, while formalin-fixed tissues were routinely processed and embedded in paraffin after $24-48 \mathrm{~h}$.

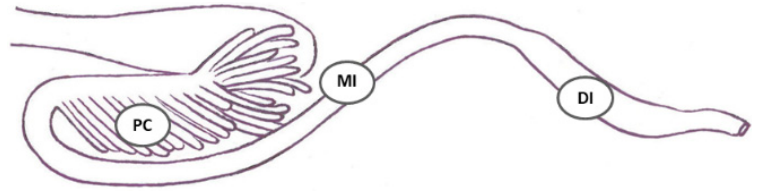

Figure 6. Sampling of intestinal tissues. Tissues from the pyloric ceca (PC), the mid-intestine (MI) and the distal intestine (DI) were collected on RNAlater and formalin. The drawing is a courtesy of Professor emeritus Inge Bjerkås, NMBU, Oslo, Norway. 


\subsection{Gene Expression Analysis by Real-Time PCR}

Nucleic acids from all intestinal tissues were extracted automatically on easyMag (bioMérieux, Marcy l'Etoile, France) using the generic protocol. The RNA concentration and purity were determined using a NanoDrop ${ }^{\mathrm{TM}} 2000$ spectrophotometer (Thermo Scientific, Wilmington, DE, USA). Purity was assessed by determining the ratio of absorbance at 260 and $280 \mathrm{~nm}$ (A260/A280). All samples had a ratio between 1.80 and 2.08. The RNA was diluted to $50 \mathrm{ng} / \mu \mathrm{L}$. The elimination of genomic DNA and the synthesis of cDNA from 500 ng RNA were performed with the QuantiTect Reverse Transcription Kit (QIAGEN, Hilden, Germany) according to the manufacturer's recommendations using the included RT Primer Mix with an optimized blend of oligo-dT and random primers dissolved in water.

Real-time PCR was carried out using SsoAdvanced Universal SYBR Green Supermix (Bio-Rad, Hercules, CA, USA) with cDNA template corresponding to $\sim 5 \mathrm{ng}$ RNA in each reaction in a CFX384 Touch $^{\mathrm{TM}}$ Real-Time PCR Detection System (Bio-Rad, Herkules, CA, USA) according to the producer's instructions with $60^{\circ} \mathrm{C}$ as annealing temperature and running 40 cycles.

The expression of markers for the following genes was analyzed by real-time PCR: claudin $25 \mathrm{~b}$, interleukin $1 \beta$ (IL-1 $\beta$ ), occludin, proliferating cell nuclear antigen (PCNA), suppressor of cytokine signaling 1 and 2 (SOCS1 and SOCS2), tricellulin, and finally elongation factor $1 \mathrm{AB}$ (EF1AB) as the reference gene [29] (see Table 2). All analyses were performed in triplicate, and a control lacking template for each master mix was always included in the experiments.

Table 2. Primers for gene expression analyses.

\begin{tabular}{|c|c|c|}
\hline Target & Gene Sequence $5 \rightarrow 3^{\prime}$ & Reference \\
\hline Claudin 25b & $\begin{array}{l}\text { F-CCTGTAAGAGGGGTCCATCA } \\
\text { R-TGACACATGTTCTGCCCTGT }\end{array}$ & [27] \\
\hline IL-1 $\beta$ & $\begin{array}{l}\text { F-GCTGGAGAGTGCTGTGGAAGA } \\
\text { R-TGCTTCCCTCCTGCTCGTAG }\end{array}$ & [30] \\
\hline Occludin & $\begin{array}{l}\text { F-GACAGTGAGTTCCCCACCAT } \\
\text { R-ATCTCTCCCTGCAGGTCCTT }\end{array}$ & [28] \\
\hline PCNA & $\begin{array}{l}\text { F-TGAGCTCGTCGGGTATCTCT } \\
\text { R-GTCCTCATTCCCAGCACACT }\end{array}$ & [31] \\
\hline SOCS1 & $\begin{array}{l}\text { F-TTCTTGATCCGGGATAGTCG } \\
\text { R-TGTTTCCTGCACAGTTCCTG }\end{array}$ & [23] \\
\hline SOCS2 & $\begin{array}{c}\text { F-CACTGCCAACGAAGCCAAAGAGAT } \\
\text { R-CAAACTGCTTCAGCTTGGGCTTGA }\end{array}$ & [23] \\
\hline Tricellulin & $\begin{array}{l}\text { F-GGATGCCATGATGGGTAAAC } \\
\text { R-AGGAAGGCTGGGTCACTCTT }\end{array}$ & [28] \\
\hline $\mathrm{EF} 1 \mathrm{AB}$ & $\begin{array}{l}\text { F-TGCCCCTCCAGGATGTCTAC } \\
\text { R-CACGGCCCACAGGTACTG }\end{array}$ & [32] \\
\hline
\end{tabular}

\subsection{Histology and Immunohistochemistry}

Sections from all intestinal tissues were cut at $3 \mu \mathrm{m}$ and stained with hematoxylin and eosin (HE) or Alcian Blue (AB) and Periodic acid-Schiff (PAS) in combination, whereas proliferating cells were detected using a monoclonal mouse antibody against proliferating cell nuclear antigen (PCNA; M0879, Dako, Glostrup, Denmark) previously used in fish [33]. After deparaffinization, antigen retrieval, and inhibition as described elsewhere [34], the sections were incubated with horse serum diluted 1:100 in 5\% bovine serum albumin (BSA) in a tris-buffer solution (TBS) for 20 min to prevent non-specific binding. The antibody against PCNA was diluted 1:5000 in 1\% BSA/TBS before incubation for $60 \mathrm{~min}$. The secondary antibody, horseradish peroxidase-labelled polymer conjugated to horse anti-mouse Ig, was diluted 1:100 in 1\% BSA/TBS before incubation for $30 \mathrm{~min}$, followed by incubation with Vectastain ${ }^{\circledR}$ Elite ABC Reagent (PK-7100, Vector Laboratories, Burlingame, CA, USA) for $30 \mathrm{~min}$ and ImmPACT ${ }^{\mathrm{TM}}$ AEC (SK-4205, Vector Laboratories, Burlingame, CA, USA) for 5 min. The sections were thoroughly rinsed between each step except after the incubation with horse serum, counterstained with hematoxylin for $15 \mathrm{~s}$ and mounted with VectaMount ${ }^{\mathrm{TM}}$ AQ Aqueous 
Mounting Medium (H-5501, Vector Laboratories, Burlingame, CA, USA). Micrographs were captured with ACT-1 software (Nikon, Tokyo, Japan) using a digital camera $\mathrm{D} \times 1200$ configured with a Leica DM4000 microscope.

\subsection{Calculations and Statistical Analysis}

Databases for the results from real-time PCR were established in Excel®for Windows, and statistical calculations and graphical presentation of gene expression were performed using Prism 7.0 software (GraphPad Software, La Jolla, CA, USA). Data were given as mean \pm standard error of the mean (SEM) unless otherwise stated. The data for gene expression were analyzed for normality using the Shapiro-Wilk test. Data with normal distributions were further analyzed using the unpaired $t$-test, whereas non-normal data were analyzed using the Mann-Whitney U test. The significance level was set to 0.05 .

Author Contributions: Conceptualization, A.B., E.O.K., G.R., M.K., and T.M.; Validation, T.M.; Formal Analysis, T.M.; Investigation, T.M.; Resources, G.R.; Data Curation, T.M.; Writing-Original Draft Preparation, T.M.; Writing-Review and Editing, A.B., E.O.K., G.R., and M.K.; Visualization, T.M.; Supervision, A.B., E.O.K, G.R., and M.K.; Project Administration, A.B.; Funding Acquisition, A.B.

Funding: The feed trial was funded by the Research Council of Norway through the project "Safe feed, safe and healthy seafood" (Project Number 199626) and Skretting ARC, whereas the laboratory work was funded by a basic grant from the Research Council of Norway to the Norwegian Veterinary Institute.

Acknowledgments: The authors would like to thank Randi Terland and Britt Saure for cutting sections and stainings; Inger Böckerman and Lone Engerdahl for the extraction of nucleic acids and the synthesis of cDNA; Maria Dahle, Søren Grove, Hilde Sindre, and Monika Hjortaas for scientific discussions; and Karen Bækken Soleim and Alexandra Bodura Göksu for their kind advice in the laboratory.

Conflicts of Interest: The authors declare no conflict of interest. The funders had no role in the design of the study; in the collection, analyses, or interpretation of data; in the writing of the manuscript; and in the decision to publish the results.

\section{References}

1. Powell, K. Eat your veg. Nature 2003, 426, 378-379. [CrossRef] [PubMed]

2. Liland, N.S.; Rosenlund, G.; Berntssen, M.H.G.; Brattelid, T.; Madsen, L.; Torstensen, B.E. Net production of Atlantic salmon (FIFO; Fish in Fish out < 1) with dietary plant proteins and vegetable oils. Aquac. Nutr. 2013, 19, 289-300.

3. Waagbø, R.; Berntssen, M.H.G.; Danielsen, T.; Helberg, H.; Kleppa, A.L.; Lea, T.B.; Rosenlund, G.; Tvenning, L.; Susort, S.; Vikesa, V.; et al. Feeding Atlantic salmon diets with plant ingredients during the seawater phase-A full-scale net production of marine protein with focus on biological performance, welfare, product quality and safety. Aquac. Nutr. 2013, 19, 598-618. [CrossRef]

4. Antonissen, G.; Martel, A.; Pasmans, F.; Ducatelle, R.; Verbrugghe, E.; Vandenbroucke, V.; Li, S.; Haesebrouck, F.; Van Immerseel, F.; Croubels, S. The impact of Fusarium mycotoxins on human and animal host susceptibility to infectious diseases. Toxins 2014, 6, 430-452. [CrossRef] [PubMed]

5. Nesic, K.; Ivanovic, S.; Nesic, V. Fusarial Toxins: Secondary Metabolites of Fusarium Fungi. In Reviews of Environmental Contamination and Toxicology; Whitacre, D., Ed.; Springer: Cham, Switzerland, 2014; Volume 228, pp. 101-120. ISBN 978-3-319-01619-1.

6. Cheli, F.; Battaglia, D.; Gallo, R.; Dell'Orto, V. EU legislation on cereal safety: An update with a focus on mycotoxins. Food Control 2014, 37, 315-325. [CrossRef]

7. Pinotti, L.; Ottoboni, M.; Giromini, C.; Dell'Orto, V.; Cheli, F. Mycotoxin Contamination in the EU Feed Supply Chain: A Focus on Cereal Byproducts. Toxins 2016, 8, 45. [CrossRef] [PubMed]

8. Sanden, M.; Hemre, G.; Måge, A.; Lunestad, B.; Espe, M.; Lie, K.; Lundebye, A.K.; Amlund, H.; Waagbø, R.; Ørnsrud, R. Program for Overvåking av Fiskefôr; Nasjonalt Institutt for Ernærings- og Sjømatforskning: Bergen, Norway, 2017; ISBN 978-82-91065-46-5.

9. Nacher-Mestre, J.; Serrano, R.; Beltran, E.; Perez-Sanchez, J.; Silva, J.; Karalazos, V.; Hernandez, F.; Berntssen, M.H.G. Occurrence and potential transfer of mycotoxins in gilthead sea bream and Atlantic salmon by use of novel alternative feed ingredients. Chemosphere 2015, 128, 314-320. [CrossRef] [PubMed] 
10. Bernhoft, A.; Høgåsen, H.R.; Rosenlund, G.; Ivanova, L.; Berntssen, M.H.G.; Alexander, J.; Eriksen, G.S.; Fæste, C.K. Tissue distribution and elimination of deoxynivalenol and ochratoxin A in dietary-exposed Atlantic salmon (Salmo salar). Food Addit. Contam. Part A Chem. Anal. Control Expo. Risk Assess. 2017, 34, 1211-1224. [CrossRef] [PubMed]

11. Bernhoft, A.; Høgåsen, H.R.; Rosenlund, G.; Moldal, T.; Grove, S.; Berntssen, M.H.G.; Thoresen, S.I.; Alexander, J. Effects of dietary deoxynivalenol or ochratoxin A on performance and selected health indices in Atlantic salmon (Salmo salar). Food Chem. Toxicol. 2018. [CrossRef] [PubMed]

12. Hooft, J.M.; Elmor, H.I.; Encarnacao, P.; Bureau, D.P. Rainbow trout (Oncorhynchus mykiss) is extremely sensitive to the feed-borne Fusarium mycotoxin deoxynivalenol (DON). Aquaculture 2011, 311, 224-232. [CrossRef]

13. Matejova, I.; Modra, H.; Blahova, J.; Franc, A.; Fictum, P.; Sevcikova, M.; Svobodova, Z. The effect of mycotoxin deoxynivalenol on haematological and biochemical indicators and histopathological changes in rainbow trout (Oncorhynchus mykiss). Biomed. Res. Int. 2014, 2014, 310680. [CrossRef] [PubMed]

14. Pietsch, C.; Katzenback, B.A.; Garcia-Garcia, E.; Schulz, C.; Belosevic, M.; Burkhardt-Holm, P. Acute and subchronic effects on immune responses of carp (Cyprinus carpio L.) after exposure to deoxynivalenol (DON) in feed. Mycotoxin Res. 2015, 31, 151-164. [CrossRef] [PubMed]

15. Alizadeh, A.; Braber, S.; Akbari, P.; Garssen, J.; Fink-Gremmels, J. Deoxynivalenol impairs weight gain and affects markers of gut health after low-dose, short-term exposure of growing pigs. Toxins 2015, 7, 2071-2095. [CrossRef] [PubMed]

16. Lessard, M.; Savard, C.; Deschene, K.; Lauzon, K.; Pinilla, V.A.; Gagnon, C.A.; Lapointe, J.; Guay, F.; Chorfi, Y. Impact of deoxynivalenol (DON) contaminated feed on intestinal integrity and immune response in swine. Food Chem. Toxicol. 2015, 80, 7-16. [CrossRef] [PubMed]

17. Bracarense, A.P.; Lucioli, J.; Grenier, B.; Drociunas Pacheco, G.; Moll, W.D.; Schatzmayr, G.; Oswald, I.P. Chronic ingestion of deoxynivalenol and fumonisin, alone or in interaction, induces morphological and immunological changes in the intestine of piglets. Br. J. Nutr. 2012, 107, 1776-1786. [CrossRef] [PubMed]

18. Ghareeb, K.; Awad, W.A.; Soodoi, C.; Sasgary, S.; Strasser, A.; Böhm, J. Effects of feed contaminant deoxynivalenol on plasma cytokines and mRNA expression of immune genes in the intestine of broiler chickens. PLoS ONE 2013, 8, e71492. [CrossRef] [PubMed]

19. Antonissen, G.; Van Immerseel, F.; Pasmans, F.; Ducatelle, R.; Haesebrouck, F.; Timbermont, L.; Verlinden, M.; Janssens, G.P.; Eeckhaut, V.; Eeckhout, M.; et al. The mycotoxin deoxynivalenol predisposes for the development of Clostridium perfringens-induced necrotic enteritis in broiler chickens. PLoS ONE 2014, 9, e108775. [CrossRef] [PubMed]

20. Amuzie, C.J.; Shinozuka, J.; Pestka, J.J. Induction of suppressors of cytokine signaling by the trichothecene deoxynivalenol in the mouse. Toxicol. Sci. 2009, 111, 277-287. [CrossRef] [PubMed]

21. Akbari, P.; Braber, S.; Varasteh, S.; Alizadeh, A.; Garssen, J.; Fink-Gremmels, J. The intestinal barrier as an emerging target in the toxicological assessment of mycotoxins. Arch. Toxicol 2017, 91, 1007-1029. [CrossRef] [PubMed]

22. Linossi, E.M.; Babon, J.J.; Hilton, D.J.; Nicholson, S.E. Suppression of cytokine signaling: The SOCS perspective. Cytokine Growth Factor Rev. 2013, 24, 241-248. [CrossRef] [PubMed]

23. Skjesol, A.; Liebe, T.; Iliev, D.B.; Thomassen, E.I.; Tollersrud, L.G.; Sobhkhez, M.; Lindenskov Joensen, L.; Secombes, C.J.; Jørgensen, J.B. Functional conservation of suppressors of cytokine signaling proteins between teleosts and mammals: Atlantic salmon SOCS1 binds to JAK/STAT family members and suppresses type I and II IFN signaling. Dev. Comp. Immunol. 2014, 45, 177-189. [CrossRef] [PubMed]

24. Fuglem, B.; Jirillo, E.; Bjerkås, I.; Kiyono, H.; Nochi, T.; Yuki, Y.; Raida, M.; Fischer, U.; Koppang, E.O. Antigen-sampling cells in the salmonid intestinal epithelium. Dev. Comp. Immunol. 2010, 34, 768-774. [CrossRef] [PubMed]

25. Løkka, G.; Austbø, L.; Falk, K.; Bromage, E.; Fjelldal, P.G.; Hansen, T.; Hordvik, I.; Koppang, E.O. Immune parameters in the intestine of wild and reared unvaccinated and vaccinated Atlantic salmon (Salmo salar L.). Dev. Comp. Immunol. 2014, 47, 6-16. [CrossRef] [PubMed]

26. Bæverfjord, G.; Krogdahl, Å. Development and regression of soybean meal induced enteritis in Atlantic salmon (Salmo salar L.) distal intestine. A comparison with the intestines of fasted fish. J. Fish Dis. 1996, 19, 375-387. [CrossRef] 
27. Tipsmark, C.K.; Sørensen, K.J.; Hulgard, K.; Madsen, S.S. Claudin-15 and -25b expression in the intestinal tract of Atlantic salmon in response to seawater acclimation, smoltification and hormone treatment. Comp. Biochem. Physiol. A Mol. Integr. Physiol. 2010, 155, 361-370. [CrossRef] [PubMed]

28. Tipsmark, C.K.; Madsen, S.S. Tricellulin, occludin and claudin-3 expression in salmon intestine and kidney during salinity adaptation. Comp. Biochem. Physiol. A Mol. Integr. Physiol. 2012, 162, 378-385. [CrossRef] [PubMed]

29. Olsvik, P.A.; Lie, K.K.; Jordal, A.E.O.; Nilsen, T.O.; Hordvik, I. Evaluation of potential reference genes in real-time RT-PCR studies of Atlantic salmon. BMC Mol. Biol. 2005, 6, 21. [CrossRef] [PubMed]

30. Marjara, I.S.; Chikwati, E.M.; Valen, E.C.; Krogdahl, A.; Bakke, A.M. Transcriptional regulation of IL-17A and other inflammatory markers during the development of soybean meal-induced enteropathy in the distal intestine of Atlantic salmon (Salmo salar L.). Cytokine 2012, 60, 186-196. [CrossRef] [PubMed]

31. Kortner, T.M.; Gu, J.; Krogdahl, Å.; Bakke, A.M. Transcriptional regulation of cholesterol and bile acid metabolism after dietary soyabean meal treatment in Atlantic salmon (Salmo salar L.). Br. J. Nutr. 2013, 109, 593-604. [CrossRef] [PubMed]

32. Løvoll, M.; Austbø, L.; Jørgensen, J.B.; Rimstad, E.; Frost, P. Transcription of reference genes used for quantitative RT-PCR in Atlantic salmon is affected by viral infection. Vet. Res. 2011, 42, 8. [CrossRef] [PubMed]

33. Løkka, G.; Austbø, L.; Falk, K.; Bjerkås, I.; Koppang, E.O. Intestinal morphology of the wild Atlantic salmon (Salmo salar). J. Morphol. 2013, 274, 859-876. [CrossRef] [PubMed]

34. Moldal, T.; Løkka, G.; Wiik-Nielsen, J.; Austbø, L.; Torstensen, B.E.; Rosenlund, G.; Dale, O.B.; Kaldhusdal, M.; Koppang, E.O. Substitution of dietary fish oil with plant oils is associated with shortened mid intestinal folds in Atlantic salmon (Salmo salar). BMC Vet. Res. 2014, 10, 60. [CrossRef] [PubMed]

(C) 2018 by the authors. Licensee MDPI, Basel, Switzerland. This article is an open access article distributed under the terms and conditions of the Creative Commons Attribution (CC BY) license (http:/ / creativecommons.org/licenses/by/4.0/). 